\title{
Audit Sistem Informasi Aplikasi Scan Barcode E-Faktur Pajak menggunakan COBIT Framework 5.0 Domain DSS pada PT. Japan Asia Consultants
}

\author{
Nur Lutfiyana ${ }^{1 *}$, Aldez Kenan Junior ${ }^{2}$, Daryanto ${ }^{3}$, Putriani Dormian Purba ${ }^{4}$, Okto Olgalina \\ Simbolon ${ }^{5}$, Veny Rahmayanti ${ }^{6}$ \\ Jurusan SISTEM INFORMATIKA , STMIK NUSA MANDIRI \\ Jl. Kramat Raya No.18, Kwitang, Senen, Jakarta Pusat. \\ *Email: nur.lutfiyana@yahoo.com
}

\begin{abstract}
Abstrak
Penerapan teknologi sekarang ini sudah merupakan suatu hal yang wajib, tidak boleh tidak didalam perusahaan. Perusahaan yang ingin mengembangkan bisnisnya akan memanfaatkan teknologi sebagai sarana pendukung kegiatan bisnisnya. Demikian pada perusahaan PT. JAPAN ASIA CONSULTANTS, yang memanfaaikan teknologi sebagai sarana untuk mendukung kegiatan bisnis. Aplikasi Scan Barcode E-Faktur Pajak merupakan pemanfaatan teknologi yang dilakukan oleh perusahaan ini. Namun ada beberapa kendala didalam penggunaan aplikasi ini. Dengan adanya kendala itu, membuat kami tertarik untuk mengaudit aplikasi ini dengan kerangka kerja COBIT domain Deliver, Service, and Support (DSS) terhadap kendala yang dialami selama penggunaan aplikasi ini. Kegiatan audit ini akan menghasilkan temuan-temuan terhadap isu yang ada dan dapat menyarankan kepada perusahaan agar pemanfaatan dan tata kelola IT berjalan dengan baik.
\end{abstract}

Kata Kunci: Aplikasi, Audit, Teknologi

\section{PENDAHULUAN}

Teknologi Informasi (TI) saat ini menjadi teknologi yang banyak diterapkan oleh hampir seluruh organisasi atau perusahaan dan diharapkan akan dapat membantu pencapaian tujuan suatu organisasi atau perusahaan. Pemanfaatan TI telah memberikan solusi dan keuntungan melalui peluang-peluang sebagai bentuk dari peran strategis TI dalam pencapaian visi dan misi perusahaan. Peluang-peluang diciptakan dari optimalisasi sumber daya TI pada area sumber daya perusahaan yang meliputi data, sistem aplikasi, infrastuktur dan sumber daya manusia.

Di sisi lain, penerapan TI memerlukan biaya investasi yang relatif mahal, dimana munculnya resiko terjadinya kegagalan juga cukup besar. Kondisi ini membutuhkan konsistensi dalam bidang pengelolaan sehingga suatu Tata Kelola TI yang sesuai akan menjadi kebutuhan yang esensial bagi perusahaan. Untuk mencapai hal tersebut diperlukan suatu pengelolaan TI yang ada secara terstruktur.

Hampir seluruh perusahaan sekarang ini sudah mengimplementasikan teknologi informasi dalam menjalankan bisnisnya, baik dengan investasi TI yang minim maupun investasi yang besar seperti sistem informasi berbasis komputer atau lebih sering dikenal dengan istilah Komputerisasi Sistem, hal ini dimaksudkan agar tujuan perusahaan bisa tercapai dengan maksimal. Begitu juga dengan PT. Japan Asia Consultants menerapkan aplikasi scan barcode e-faktur pajak untuk mempermudah pekerjaan sehingga lebih efektif dan efisien serta mengurangi terjadinya kesalahan yang dilakukan oleh user.

Untuk setiap investasi yang dilakukan perlu diketahui atau diukur tingkat efektifitas dan efisiensi yang dihasilkan, agar perusahaan benar-benar merasakan value dari implementasi TI tersebut. Maka dari itu, Aplikasi Scan Barcode E-faktur Pajak menjadi bahan dari audit sistem informasi menggunakan Framework COBIT 5.0 dengan domain Deliver, Service, and Support (DSS) untuk mengukur efektifitas dan efisiensi operasional yang perusahaan lakukan seberapa besar.

\section{LANDASAN TEORI}

Ada beberapa definisi tata kelola TI (IT Governance) menurut sumber yang berbeda. 
Menurut Brown and Magill (1994); Tata Kelola TI menerangkan tanggung jawab untuk fungsifungsi TI. Van Grembergen (2002); Tata Kelola TI adalah suatu kapasitas organisasi oleh pimpinan, manajemen eksekutif dan manajemen TI untuk mengontrol formulasi dan implementasi strategi TI serta menjamin peleburan bisnis dan TI. Weill and Vitale (2002); Tata Kelola TI menerangkan keseluruhan proses pada suatu perusahaan untuk membagi keputusan yang benar mengenai TI dan mengawasi kinerja investasi TI. IT Governance Institute (2004); Tata Kelola TI adalah tanggungjawab pimpinan direktur dan manajemen eksekutif ". Merupakan bagian integral tata kelola perusahaan dan terdiri dari kepemimpinan dan struktur organisasi serta proses-proses yang menjamin bahwa organisasi TI dapat mendukung dan memperluas sasaran serta strategi organisasi. IT Governance Institute (ITGI) mendefinisikan tata kelola TI sebagai tanggung jawab eksekutif dan dewan direktur, dan terdiri atas kepemimpinan, struktur organisasi serta proses-proses yang memastikan TI perusahaan mendukung dan memperluas obyektif dan strategi organisasi. Tujuan tata kelola TI adalah agar dapat mengarahkan upaya TI, sehingga memastikan performa TI sesuai dengan pemenuhan obyektif berikut:

1. TI selaras dengan perusahaan dan realisasi keuntungan yang dijanjikan.

2. Penggunaan TI memungkinkan perusahaan mengeksploitasi peluang dan memaksimalkan manfaat.

3. Penggunaan sumber daya TI yang bertanggung jawab. Manajemen yang tepat akan resiko yang terkait $\mathrm{TI}$.

Implementasi tata kelola TI yang baik dan efektif mensyaratkan mekanismemekanisme pengelolaan yang harmonis, serta sesuai dengan tujuan bisnis dan kinerja yang diinginkan. Harmonisasi tersebut dilakukan secara vertikal dan horizontal sebagaimana gambar 1. berikut ini:

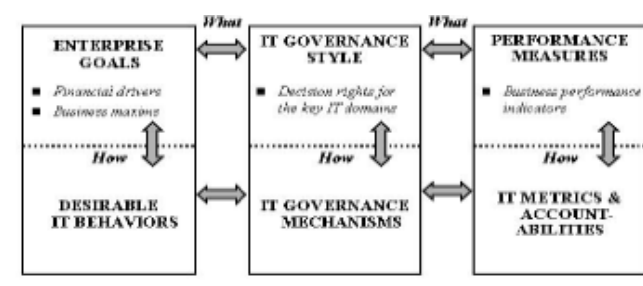

Sumber: ITGI (2005)

Gambar 1. Harmonisasi "What" dan "How" dalam IT Governance.

Harmonisasi vertikal menentukan pencapaian tujuan bisnis yang dicerminkan dalam target perilaku TI yang diharapkan; pengimplementasian IT Governance melalui mekanisme-mekanisme pengambilan keputusan; serta pencapaian target kinerja berdasarkan pengukuran kinerja TI. Sedangkan harmonisasi horisontal adalah harmonisasi baik antara tujuan bisnis, model tata kelola TI serta target kinerja bisnis, maupun antara target perilaku TI, mekanisme tata kelola TI dan ukuran-ukuran kinerja TI.Menurut Wikipedia, Teknologi Informasi atau dikenal juga dengan istilah Telematika dalam http://id.wikipedia.org/wiki/Teknologi_informa si diartikan sebagai hasil rekayasa manusia terhadap proses penyampaian informasi dari pengirimke penerima sehingga lebih cepat, lebih luas sebarannya dan lebih lama penyimpannya.

\section{A. COBIT}

Menurut (Ekowansyah et al., 2017) COBIT merupakan singkatan dari Control Objectives for Information and Related Technology, merupakan salah satu kerangka kerja (framework) dalam mendukung tata kelola teknologi informasi. Prinsip dasar pada framework COBIT adalah menyediakan informasi yang diperlukan untuk mencapai tujuan perusahaan atau organisasi. Perusahaan atau organisasi perlu mengatur dan mengatur sumber daya teknologi informasi dengan menggunakan sekumpulan proses teknologi informasi yang terstruktur sehingga dapat memberikan informasi yang dibutuhkan.

\section{B. COBIT 5}

Menurut (ISACA., 2012) Cobit (Control Objectives for Information and Related Technology) diperkenalkan pada tahun 1996 oleh ISACA (The Information System Audit and Control Assosiation). COBIT adalah kerangka kerja tata kelola IT (IT Governance Framework) dan kumpulan perangkat yang mendukung dan memungkinkan para manager 
untuk menjembatani jarak (gap) yang ada antara kebutuhan yang dikendalikan (control requirement), masalah teknis (technical issues) dan resiko bisnis (bussiness risk). COBIT 5 adalah sebuah versi pembaharuan yang menyatukan cara berpikir yang mutakhir di dalam teknik-teknik dan tata kelola TI perusahaan. Menyediakan prinsip-prinsip, praktek-praktek, alat-alat analisa yang telah diterima secara umum untuk meningkatkan kepercayaan dan nilai sistem-sistem informasi. COBIT 5 dibangun berdasarkan pengembangan dari COBIT 4.1 dengan mengintegrasikan Val IT dan Risk IT dari ISACA, ITIL, dan standarstandar yang relevan dari ISO.

\section{Prinsip COBIT 5}

1. Meeting stakeholders needs (Memenuhi keinginan pemangku kepentingan) Perusahaan menciptakan nilai bagi stakeholder dengan mempertahankan keseimbangan antara realisasi manfaat dan optimalisasi risiko serta penggunaan sumber daya.

2. Covering the enterprise end-to-end (Mencakup Enterprise End-to-end) Mengintegrasikan tata kelola perusahaan TI dalam tata kelola perusahaan: mencakup semua fungsi dan proses dalam perusahaan menganggap semua tata kelola dan manajemen TI enabler untuk perusahaan.

3. Applying a single integrated framework (Menerapkan Single Framework yang Terpadu) Berkaitan dengan IT standar dan praktik terbaik, masing-masing memberikan bimbingan pada subset dari kegiatan TI.

4. Enabling a Holistic Approach (Mengaktifkan tata Pendekatanyang menyeluruh) Manajemen TI perusahaan yang efisien dan efektif memerlukan pendekatan yang menyeluruh, mempertimbangkan beberapa komponen yang berinteraksi. Cobit 5 mendefinisikan satu set enabler untuk mendukung pelaksanaan tata kelola yang komprehensif dan sistem manajemen TI untuk perusahaan.

5. Separating Governance from Management (Memisahkan Tata Kelola dari Manajemen) Kerangka COBIT 5 membuat perbedaan yangjelas antara tata kelola dan manajemen. Kedua hal tersebut mencakup berbagai jenis kegiatan, memerlukan berbagai struktur organisasi dan melayani tujuan yang berbeda.

\section{Orientasi Proses}

1. Deliver, Service and Support (DSS)

Deliver, Service and Support (DSS) Domain ini berkaitan dengan pengiriman aktual dan dukungan layanan yang dibutuhkan, termasuk pemberian layanan, pengelolaan keamanan dan kontinuitas, dukungan layanan untuk pengguna, dan pengelolaan data dan fasilitas operasional.

\section{DSS1 - MANAGE OPERATIONS DSS2-MANAGE SERVICE REQUEST AND INCIDENTS \\ DSS3 - MANAGE PROBLEMS \\ DSS4 - MANAGE CONTINUITY \\ DSS5 - MANAGE SECURITY SERVICES \\ DSS6 - MANAGE BUSINESS PROCESS CONTROLS}

\section{E. Model Kematangan Cobit}

Menurut (Firmansyah, 2015) Proses TI yang diidentifikasi CobiT 5 dapat diukur tingat kematangannya. Capability Level yang diberikan oleh CobiT terdiri dari 6 yaitu level 0 (Incomplete) sampai 5 (optimised). Keenam level tersebut adalah:

1. Level 0: Incomplete Process/ Organisasi pada tahap ini tidak melaksanakan proses proses TI yang seharusnya ada atau belum berhasil mencapai tujuan dari proses TI tersebut.

2. Level 1: Performed Process $l$ Organisasi pada tahap ini telah berhasil melaksanakan proses TI dan tujuan proses TI tersebut benar-benar tercapai.

3. Level 2: Managed Process / pada tahap ini, Organisasi pada tahap ini dalam melaksanakan proses TI dan mencapai tujuannya dilaksanakan secara terkelola dengan baik, sehingga ada penilaian lebih karena pelaksanaan dan pencapaiannya dilakukan dengan pengelolaan yang baik. Pengelolaan berupa proses perencanaan, evaluasi dan penyesuaian untuk ke arah yang lebih baik lagi.

4. Level 3: Established Process Organisasi pada tahap ini memiliki proses-proses TI yang sudah distandarkan dalam lingkup organisasi secara keseluruhan. Artinya sudah memiliki standar proses yang berlaku diseluruh lingkup organisasi tersebut. 
5. Level 4: Predictable Process / pada tahap ini, Organisasi pada tahap ini telah menjalankan proses TI dalam batasanbatasan yang sudah pasti, misalkan batasan waktu. Batasan ini dihasilkan dari pengukuran yang telah dilakukan pada saat pelaksanaan proses TI tersebut sebelumnya.

6. Level 5: Optimizing Process / pada tahap ini, Pada tahap ini, organisasi telah melakukan inovasi-inovasi dan melakukan perbaikan yang berkelanjutan untuk meningkatkan kemampuannya.

Menurut (Pratama, 2018) ISO/IEC 15504-2:2003 ini sengaja diadopsi oleh COBIT 5 untuk Model Penilaian Proses (Process Assessment Model). Seperangkat persyaratan minimum yang ditetapkan dalam ISO/IEC 15504-2:2003 memastikan bahwa hasil penilaian adalah objektif, berimbang, konsisten, berulang dan merupakan representatif dari proses yang dinilai.

\section{BAHAN DAN METODE}

Penelitian dilakukan melalui beberapa tahapan diantaranya adalah observasi lingkungan penelitian, penyusunan kuesioner berdasarkan area penelitian, penentuan sampel penelitian, pendistribusian kuesioner, uji validitas kuesioner, perhitungan nilai kematangan, dan analisis nilai kematangan.

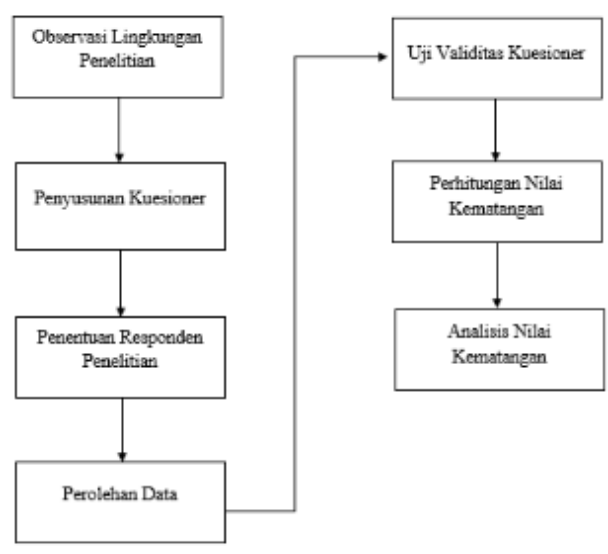

Gambar 2. Tahapan penelitian

\section{Observasi lingkungan penelitian}

Proses observasi lingkungan dilakukan dengan mendatangi langsung ke kantor PT Japan Asia Consultants dan melakukan wawancara kepada IT terkait dan User yang menggunakan program tersebut untuk melihat fenomena yang terjadi pada program yang dirasa mengganggu kegiatan operasional perusahaan. Dari fenomena tersebut kemudian dapat dijadikan dasar untuk memperkuat penelitian. Fenomena yang pernah terjadi diantaranya adalah hilangnya data PT Client, NPWP tidak valid, tidak bisa menambah data client, respon program lama, alat scan barcode tidak compatibel dan aplikasi scan barcode kadang tidak terhubung/connect.

\section{Penyusunan kuesioner}

Penyusunan kuesioner digunakan sebagai alat untuk memperoleh data sehingga penelitian dapat dilakukan. Kuesioner disusun dengan mengikuti panduan CobiT 5 yang mengambil setiap proses pada domain Cobit untuk dijadikan butir-butir pertanyaan.

\section{Penentuan responden penelitian}

Responden penelitian dibutuhkan untuk melakukan perolehan data. Tahap penentuan responden dilakukan dengan menentukan responden yang dianggap mengetahui keadaan program tersebut.

\section{Perolehan data}

Data yang diperoleh adalah data primer atau data yang diperoleh langsung dari hasil pengisian kuesioner yang diberikan kepada responden. Data tersebut diperoleh dengan mendistribusikan kuesioner secara langsung kepada responden penelitian.

\section{Uji validitas kuesioner}

Kuesioner yang telah diisi oleh responden kemudian dilakukan uji validitas untuk memastikan bahwa butir-butir pertanyaan yang diberikan telah valid menggunakan aplikasi perhitungan statistik SPSS. Tujuan uji validitas instrument dalam penelitian adalah untuk memastikan secara statistik apakah butir pertanyaan yang digunakan dalam penelitian valid atau tidak dalam arti dapat digunakan untuk pengambilan data penelitian.

\section{Perhitungan nilai kematangan}

Maturity level diperoleh dengan menghitung setiap jawaban yang diberikan oleh responden dikalikan dengan bobot setiap jawaban yang telah ditentukan kemudian dibagi dengan total pertanyaan. Pilihan jawaban yang diajukan menggunakan skala likert sebanyak 6 jawaban yang mewakili level maturitydari CobiT (level 0-5). Rumus perhitungan nilai maturity adalah sebagai berikut. 
NilaiMaturity =

\section{¿(jawabanxbobot) / Spertanyaan}

\section{Analisis nilai kematangan}

Analisis nilai kematangan dilakukan dengan membandingkan kondisi organisasi saat ini yang diperoleh dari pendistribusian kuesioner dengan kondisi yang diharapkan organisasi yang diketahui dari rencana strategis organisasi.

\section{METODOLOGI PENELITIAN}

Dalam penelitian ini menggunakan model kapabilitas sebagai alat ukur yang dibuat berdasakan kerangka kerja COBIT 5.0 yang berasal dari domain Deliver, Service, and Support (DSS), yaitu:

\section{Manage operations (DSS01).}

Koordinasi pelaksanaan kegiatan dan prosedur operasional yang dibutuhkan untuk menyediakan layanan bagi pihak internal maupun eksternal, termasuk juga pengawasan pelaksanaan prosedur operasional standard. Pada proses ini terdiri dari 5 sub-proses. Temuan dari hasil audit sebagai berikut: Belum adanya SOP yang menjabarkan urutan dan interaksi antar proses

2. Manage service requests and incidents (DSS02).

Memberikan respon yang tepat waktu dan efektif untuk permintaan pengguna dari semua jenis insiden. Pemulihan setelah insiden terjadi, dengan melakukan merekam, menyelidiki, mendiagnosa, dan menyelesaikan insiden. Pada proses ini terdiri dari 7 sub-proses. Temuan dari hasil audit sebagai berikut: User yang menggunakan program tersebut belum di training

\section{Manage problems (DSS03).}

Identifikasi dan klasifikasi permasalahan dan akar penyebab yang kemudian memberikan solusi yang tepat guna untuk mencegah insiden berulang. Juga memberikan rekomendasi untuk perbaikan. Pada proses ini terdiri dari 5 sub-proses. Temuan dari hasil audit sebagai berikut: Tidak adanya $e$-book troubleshooting untuk mengatasi problem yang muncul
4. Manage continuity (DSS04).

Pembangunan dan pemeliharaan rencana bisnis dan TI dalam menanggapi insiden dan gangguan demi kelanjutan operasional proses bisnis juga menjaga ketersediaan informasi pada tingkat yang dapat diterima oleh perusahaan. Pada proses ini terdiri dari 8 sub-proses. Temuan dari hasil audit sebagai berikut :

1. Terjadinya gangguan sinkronasi validasi data yang memakan waktu yang lama

2. Terjadinya gangguan pada saat scan jika hardcopy dokumen barcode memiliki resolusi yang tidak bagus/buram

5. Manage security services (DSS05).

Perlindungan informasi perusahaan untuk mempertahankan tingkat risiko keamanan informasi dititik minimum sesuai dengan kebijakan keamanan. Membangun dan mempertahankan peran keamanan informasi dan hak akses serta melakukan pemantauan keamanan. Pada proses ini terdiri dari 7 sub-proses.

1. PC user tidak ada antivirus

2. PC user ada antivitus tapi tidak update

3. Tidak melakukan scan antivirus secara berkala

6. Manage business process controls (DSS06). Pendefinisian dan pemeliharaan kontrol bisnis proses yang tepat dalam memastikan informasi yang terkait, baik yang diproses oleh in-house maupun outsource. Juga mengidentifikasi persyaratan kontrol informasi yang relevan dan mengelola dan kontrol pengoperasian yang memadai untuk memastikan bahwa informasi dan pengolahan informasi telah memenuhi persyaratan. Pada proses ini terdiri dari 6 sub-proses. Temuan dari hasil audit sebagai berikut: dokumen hardcopy hilang

Dari temuan-temuan hasil audit ini, kami menyarankan sebagai berikut :

1. Agar membuat SOP yang menjabarkan urutan dan interaksi antar proses

2. Agar memastikan bahwa user sudah ditraining sebelum menggunakan aplikasi

3. Agar dibuatkan e-book troubleshooting untuk aplikasi tersebut 
4. Agar program diupdate oleh developer sehingga tidak terjadi bugs/error

5. Agar setiap PC wajib mempunyai antivirus dan update antivirusnya secara berkala

6. Agar PC user dibuatkan schedule scan antivirus secara berkala

7. Agar menjaga dokumen hardcopy efaktur pajak dengan rapih

8. Agar dokumen hardcopy terlihat jelas/ resolusi yang tinggi

\section{KESIMPULAN DAN SARAN}

Bedasarkan hasil pembahasan dengan menggunakan kerangka COBIT 5.0 dengan domain deliver, service dan support bahwa temuan-temuan mengenai isu dari program scan barcode effaktur pajak bahwa belum adanya SOP yang menjabarkan urutan dan interaksi antar proses, user yang menggunakan program tersebut belum di training, Tidak adanya $e$-book troubleshooting untuk mengatasi problem yang muncul, Terjadinya gangguan sinkronasi validasi data yang memakan waktu yang lama, Terjadinya gangguan pada saat scan jika hardcopy dokumen barcode memiliki resolusi yang tidak bagus/buram, PC user tidak ada antivirus, PC user ada antivitus tapi tidak update, Tidak melakukan scan antivirus secara berkala, dokumen hardcopy hilang dan kami menyarankan Agar membuat SOP yang menjabarkan urutan dan interaksi antar proses, Agar memastikan bahwa user sudah ditraining sebelum menggunakan aplikasi, Agar dibuatkan e-book troubleshooting untuk aplikasi tersebut, Agar program diupdate oleh developer sehingga tidak terjadi bugs/error, Agar setiap PC wajib mempunyai antivirus dan update antivirusnya secara berkala, Agar PC user dibuatkan schedule scan antivirus secara berkala, Agar menjaga dokumen hardcopy e-faktur pajak dengan rapih, Agar dokumen hardcopy terlihat jelas atau resolusi yang tinggi.

\section{DAFTAR PUSTAKA}

Ekowansyah, E., H, C. Y., Puspita, \& Sabrina, N. (2017). Audit Sistem Informasi Akademik Menggunakan COBIT 5 di Universitas Jenderal Achmad Yani. Prosiding Seminar Nasional Komputer Dan Informatika (Senaski) 2017 (ISBN: 978 - 602 - 60250 - 1-2), 2017, 201-206. https://doi.org/10.1371/journal.pone.0197 468
Firmansyah, D. (2015). Pengukuran Kapabilitas Pengelolaan Sistem Informasi Sub Domain Deliver, Service, Support 01 Menggunakan Framework Cobit 5 Studi Kasus: Politeknik Komputer Niaga LPKIA Bandung. Konferensi Nasional Sistem \& Informatika, 9-10.

ISACA. (2012). COBIT 5: A business framework for the governance and management of enterprise IT. Isaca.

Pratama, H. (2018). Audit Keamanan Sistem Informasi Pada Kantor Samsat Di Kota Krui Menggunakan Cobit 5. Universitas Mitra Indonesia, 2015(Sentika), 17-21. 